\title{
Case study of Urban and Rural Women Journalists in India
}

\author{
Md Afsar ${ }^{1}$, Suman Kumari ${ }^{2}$ \\ ${ }^{1} \mathrm{PhD}$ Research Scholar, Department of Journalism and Mass Communication, FMeH, MRIIRS, Faridabad \\ ${ }^{2}$ Associate Professor, Department of Journalism and Mass Communication, FMeH, MRIIRS, Faridabad
}

\begin{abstract}
In our country, women journalists, specifically those living in urban areas, have been successful in making a mark in the news media profession. Though, it is also true that the opportunities which rural female reporters gets are less in comparison to those women journalists who live in urban areas gets. Therefore, this also leads to the difference in their professional, economic and social lives. Furthermore, in our country, the perception by the society towards female reporters also differs for those working in urban and rural parts. Therefore, there is a need to present a case study of the experiences of the urban and rural women journalists. The aim of the paper is to present the study of the life of urban and rural women journalists to understand the differences between their professional, economic and social lives. The study will help in understanding the gap between the actual and perceived social, economic and professional conditions of female reporters.
\end{abstract}

Keywords: Woman Journalist, Experience, Reality, Perception 


\section{Social science, Humanities \& Education}

15 - 17 December, 2020

Berlin,Germany

\section{Introduction}

Over the years, there have been a number of social changes in our country and the news media has played a vital role in bringing these changes. The news media has the potential to make the people's views on the political, social and economic matters. The news media has also been a part of the journey in the empowerment of females in our country, especially of the female reporters [1,2]. In this way, the females have been successful in their growth in terms of their professional as well as social status. Female reporters in India have overcome the hurdles in their professional career and also have shown their journalistic capabilities $[3,4]$.

In the contemporary times, the visibility and number of the women journalists in the urban news media has substantially increased in the leading TV news channels. People think that in these times, the women do not face any hindrances to join and work in the news media $[5,6]$. Conversely, women journalists face struggle to get a job in this profession and also face restricted growth. Limited news beats are, generally, assigned to them such as entertainment, sports etc. which men thinks they can do. This way, we can see that what the people perceive may be different from the reality of the urban women journalists $[7,8]$.

It is generally perceived that the rural women journalists seem to be less competent and less professional in their work. Conversely, in the last few years, the problems related to the rural areas are very well highlighted in the news media by the rural women journalists. In this way, they have been successful in helping the people living in rural areas to deal with their issues. The news media in rural areas have considerably grown in the past few years. One of the successful rural news media is Khabar Lahariya [9]. The newspaper is run by all women and has been proficiently addressing the issues of the rural people to the concerned authorities to fight for their rights such as education, gender equality and social rights [10]. The mainstream news media, generally, do not give space to the rural issues and therefore, we can see the need of the rural news media. Rural women journalists have been, to some extent, successful in overcoming the social and cultural constraints which prevails quite deeply till date in the 


\section{Social science, Humanities \& Education}

15 - 17 December, 2020

Berlin,Germany

rural areas. Again, we see that the perception and reality of the rural women journalists seems to be way different from each other.

Therefore, there is a need to conduct case study to explore the perception and reality of the female journalists who have succeeded in sidelining the patriarchal thinking of the society to grow in their profession. This paper aims to provide an insight into the actual and perceived lives of women journalists in our country.

The main objectives of our research are as follows.

1. To conduct the case study of the urban women journalists in terms of professional, social and personal lives.

2. To conduct the case study of the rural women journalists in terms of professional, social and personal lives.

The paper is organized in the following sections. Section 2 describes the work that has been done related to our research areas in the paper. The case study of the urban women journalists in terms of professional, social and personal lives is presented in section 3. Section 4 presents case study of the rural women journalists in terms of professional, social and personal lives. The paper is finally concluded in the Section 5.

\section{Related Work}

In this section, we present the related research work which has been done in our underlying area.

Author in [12] advocates for the application of the theory of liberal feminism on female correspondents. Also, the author says that each and every person must be given the same rights. He also agrees on the fact that female have been given very limited opportunities in their career. This may be due to the male-controlled thinking of our society.

The number of women who pursue their career and job in our country is the lowest among several countries worldwide [14]. Nevertheless, since last few years, this number has significantly risen. The news media profession was considered to be the men dominated 


\section{Social science, Humanities \& Education}

15 - 17 December, 2020

Berlin,Germany

profession, but now more number of female are also allowed to work [15]. Research work done in [17] analyzed that women in any profession can be easily targeted for discrimination in terms of professional career. Women journalists do face verbal harassment in their organizations that they cannot outperform male in this profession [20]. The author in [21] has studied that female are mostly assigned light news beats and are not given the opportunity to write the editorial section. The critical and sensitive issues be it political, economic or social, they are given less preference to cover them as compared to men. Very less female hold key positions in news media organizations [22]. Working women are harassed and are mostly used for beautification of news.

Authors in [23] studied that the status of female reporters in urban areas in terms of the involvement in print news media. They have also suggested some of the measures so as to enhance the quality of the professional lives of the women in print media. The work also highlights that women are very less on the higher level positions as compared to male in their organizations.

The women living in rural areas have started to pursue journalism as their career. One of the examples is the newspaper called Khabar Lahariya which is completely run by women who are living in the rural areas $[9,10]$. However, they face a lot of problems while doing their job in terms of the societal challenges they face in day today's life. In spite of all the problems, they have been successful in proving themselves good at their job and have helped the rural people in many ways by highlighting their issues in news media [24].

People in India have different perceptions about the lives of the women working in news media profession for those living in rural and urban areas. But, this is not necessary that the perception and truth of women journalists is same be it for the urban or rural female journalists. This arise the need to study the differences in the perception and realism of women journalists in India and also the factor which help in defining this difference.

It is clearly understood from the aforementioned that a research gap is present regarding the case study about the female journalists in our country. Therefore, our paper focuses on to present the case studies of the female journalists. 


\section{Social science, Humanities \& Education}

15 - 17 December, 2020

Berlin,Germany

\section{Case Study of Urban Women Journalists}

A senior journalist Sneha Tandon is currently working with Times of India. She has started her career in news media back in 2005. She has worked with various news media organizations. She said "Working as a journalist was always my dream since my school. Journalism is my passion. I have given always my level hard to do my job irrespective of the location of news story or time to cover the news story. One thing which I feel I have not got what I deserved is the news beats which are assigned to me. I have not got hard news beats which my male colleagues get. Mostly, I get news beats of entertainment, health and education." On the personal life, she shared that she feels very hectic in her daily schedule of balancing her personal and professional life. She does not get enough time to spend with her family because of the overloaded work in her office.

Manisha Kulshreshtha is a senior news producer who is working with News24 TV news channel. She has about 13 years of work experience in different news media organizations. About her professional life, she said "I have always enjoyed working in news media and doing my job. I feel my responsibility to not to make a tiny mistake while my news story is going to be aired. I always intend to write news story which is rich in content and give knowledge to the viewers. Though, I feel that I am not appreciated in terms of my work and also in terms of my salary package. I have tried to raise my concern for a good appraisal in my salary but have not been heard. I always want to cover news story which are related to economy as I have done my Masters in Economics with one of the finest institution in our country. But I have been given only soft news beats to cover." When asked about her social life, she said that she always feel sleep deprivation in her body because when she work in morning shift, she sleeps late night after completing all her household works and when she work in night shift, she has to work during the day for home work and caring her kids. She feels that she never complaints about her hectic schedule but feels that she should be given some kind of appreciation and also respect for her professional work at her workplace.

During our interviews, we have interacted with the senior journalist Amita Nandal who is currently working in Republic TV. She said that she has been working in news media for the last eleven years. She started her journalism career in 2009 and since then she is continuously 


\section{Social science, Humanities \& Education}

15 - 17 December, 2020

Berlin,Germany

working with sheer hard work and dedication. She has gained a lot of experience in terms of different roles in news media such as she has worked in both input and output department. She has done news reporting in the input department as well as worked as news producer in the output department in various news organizations. She has shared her professional life in her current organization. She says that at workplace, she feels safe and secured. The organization provides her cab facility. In terms of the work, she agrees on enjoying her work in spite of the work pressure at times. But she work honestly with her full efforts during the working hours in her office. She said that "I feel safe in my office because my colleagues always behave very professionally with female colleague. They always give respect to me. We work together; we eat lunch or dinner together. We enjoy our work company. Especially in my department, there is less number of male employees as compared to female employee. The company anyways appreciate female employee. Talking about her salary, she says that the organization gives her adequate salary along with the medical benefits. When asked about her experience with the male colleagues, she said that in the news media organization, pay grade, designation and job profile are based on one's work experience. Therefore, different media workers have different post and salary. However, in terms of the work, the post or pay does not matter but what matters are the news stories and other related assigned work which everyone whether it is senior or junior, has to complete. Everyone in the office works as a team. We had a discussion about her personal and social life. She said that "My personal life is my family and my old parents. After office, I always love to spend time with my old parents. We enjoy having tea together. As I am still single, so I and my family face a lot of society pressure. Though, that's not possible for me because I have to take care of my old parents and I can't leave them alone." When asked about the perception of society towards her personal and social life, she said, "A good thinking and good carrier opportunities always make you proud in society. People always respect me and my parents. They always use to say that a journalist girl in our society makes us proud."

Another female journalist Sarika Jain who works in India News channel as news producer shared some of her experiences during the interview. She said that she has been working in news media profession since last 12 years. She said that she has faced a lot of struggle in sustaining her job in this profession and also she has gone beyond the limits of hard work to 


\section{Social science, Humanities \& Education}

15 - 17 December, 2020

Berlin,Germany

achieve some success in her career growth. She also said that she had to do extra work as compared to her male colleagues to prove her journalistic capabilities. Talking about her salary, she said "I am not satisfied with the pay which get. I work so hard with utmost sincerity towards my work and therefore, I expect deserving remuneration. I get very less salary as compared to my male colleagues who have equal amount of experience and job profile." She is also not satisfied with the work environment in her office towards her such as extra-long working hours etc. On her personal life, she has very less to share. The only thing she has shared was that she feels happy as she gets full support from her family.

A journalist Kusum Singh who works in the Lucknow bureau of The Mirror newspaper outraged to say that the gender is the area of concern in our society for the working women since so many decades in India. But, on the name of gender, especially in news media world, women should not ask for favours. Instead they should fight for the equality in terms of the work which is assigned to them. Asking favours is against the spirit of journalism, according to her. There is a need to improve the scope of bringing gender equality in our system.

kids and family members. They have to do both family work and also their office work.

Women in general plan their kids with their job work quantity or because of the demands of the profession. A senior journalist Avantika Gunjan said during her interview that "There are few news media organisations which come forward in helping women with their kids but most of the organizations women do all of their work on their own including childcare duties. It would be very helpful if female journalists get childcare facilities at their workplace so that they can concentrate on their news stories instead of worrying about leaving the kid with an untrustworthy maid. This would encourage young mothers to join or continue their job in their organizations."

In an interview with a news stringer Deepika Singh, it was revealed that the unmarried female do get pressurized by their family members especially their parents for marriage. She said that "Married women are forced by their in-laws and also by their husbands to leave their organizations and do the household work." However, the situation is changing day by day for 


\section{Social science, Humanities \& Education}

15 - 17 December, 2020

Berlin,Germany

the women journalists. They are supported by their husbands and their families to continue their work when they want to.

One of the senior journalists Meenakshi Sinha who works in the national newspaper Business Standard said that the circulation of the newspapers in a way makes a difference in the salary which the journalist gets.

One of news producer, Rekha Vashishth, said that she agrees on the sense of insecurity among female reporters and that many of the female journalists try to pursue other professions. This is sometimes due to the work which is assigned to them or due to the unsatisfactory salary packages. This in turn results in the recruitment of less experienced and less educated journalists in the news media profession. Among these non-deserved candidates, some of them cannot even write a simple sentence of a news story or cannot say a single line during the PTC or Live in English or Hindi.

A senior correspondent in a leading news channel, Avantika Singh, shared her experience of job in the interview with us. She is currently working with Lokmat newspaper. She said that the irrespective of the tough situations, she has always worked with full dedication and has not given any kind of leniency in performing any of my job assigned to me. Many of the female journalists have started to pursue their career in other fields in which there is more job security and secured future. She also talked about the exploitation done against women in the news media profession in which when women raises her voice they are either demoted or expelled from their job, sometimes without even a formal notice. She raised a concern about these kinds of ill practices against women journalists in the field of journalism. The security of women's job has been granted neither by our judicial system nor the society stand against these ill practices.

Sumati Karan is a correspondent in CNBC Awaaz who shared her news media work experience in terms of the salary and pay incentives given to her by the current and previous news media organizations. She said that "When I was expecting my second child, I requested for the maternity leaves and the incentives but the HR department said that they will not give me any maternity leaves. When I asked for the reason for not giving me the maternity leaves, 


\section{Social science, Humanities \& Education}

15 - 17 December, 2020

Berlin,Germany

they asked me to leave the organization." She also said that "However, there are provisions of maternity leaves and other incentives for women in almost all the sectors. There is reluctance in the hiring of women candidates some of the times for the same reason. Female journalists should be given some kind of incentives either in terms of the workload or in terms of the wages." When women come after the maternity break, they are generally not given the promotions and the related job incentives.

In an interview with the principal correspondent Ms. Shikha Shrivastava, we got to know more about the job incentives given to the female journalists. She shared her experience "I am working in my current organization on contract. At the end of each month, I have to sign on the register to get my salary just like a daily wage labour sign and get the money. I have not got any job incentives because I am on contract. This is a situation with many of the female journalists who are forced to be at the mercy of the management. We all have to accept the contract system to continue the job in news media." This exploitation forces some of the female journalists to start a new career in any other field other than the news media. Among the female journalists, there is a variation of the daily wages who work on the contract basis. There should be some policies which should be adopted by the news media institutions to increase the job incentives for female employees to increase the women participation in this profession.

A news reporter Rachna Upadhyay shared her experiences in news media in our interview. She is currently working TV18 news channel. She said that "I have been working in the news media profession since last four years. I am not fully satisfied with the kind of work which I have been assigned but it has been a learning experience for me in the news media profession. I am also not satisfied with the amount of salary which I should get because of the amount of the work which I do. “

Regarding her experience, she also said that "In the fast forward profession like news media, safety of women is unseen. I have to go to the places for news story coverage where I get afraid to do the reporting and I do not get enough security at those places. But what to do, I need to save my job first and have to complete the task which I have been given. In spite of all these hardships, I enjoy my work a lot. I work under a lot of pressure with almost no 


\section{Social science, Humanities \& Education}

15 - 17 December, 2020

Berlin,Germany

leaves and working for $24 * 7$ hours. There is no job security in news media according to me. I do not know whether I willl be allowed to work in the next day or not because there is no job gurantee. But I enjoy my work, my job as I have chosen this profession and it's my choice to pursue my career in news media."

\section{Case Study of Rural Women Journalists}

A reporter from Bhagalpur Times newspaper, Bhanumati Kumari, is working in news media since last four years. She is currently covering political news beat in her organization which is a rural newspaper. She said that when once she went for an interview of the MLA, she was asked to ask only those questions which will be given to her by the MLA office. In response to this, she said that she will take those given questions but will ask by herself. She was even scolded for her response and was also told that she is a female and female reporter that too from rural background does not have any journalistic news sense. She said that this is the kind of perception which the society has about the rural women journalists. Next, she said that after listening to their response, she said that it is upto the MLA to answer my questions and also that she will not leave until she asks all he questions. They had no choice but to allow me to take the interview. After the interview, the MLA praised me and was highly impressed by my knowledge and confidence. She said that "I am not worried about the perception of the people about my job because I am confident about my work and my eagerness to learn more and more about this profession. This makes me going in my job. Your talent will keep everybody's mouth shut"

In an interview with Sunaina Yadav who is working as a correspondent in Gaon Connection newspaper in Lucknow revealed that when she started her job, she got mentally harassed by not only her in laws but by her parents also. They tried very hard to stop her from pursuing career in journalism as they think that this profession is not for females. She said "My husband even said that you do not want to be with and take care of the family and that's why you want to do journalism. He even said that I want to show him lower to the family." She was very depressed by her family behaviour but she managed to start her journalism career. She says that this is a common story of a rural woman journalist in India. They all have to fight against the patriarchal perception of the society towards rural women. In reality, women 


\section{Social science, Humanities \& Education}

15 - 17 December, 2020

Berlin,Germany

from rural areas have so much talent which remains unexplored just because they are seen as a household worker only in the rural parts of our country.

The interview with the reporter of Ara Patrika, Arpita Kumari shared her experiences about her professional and personal life as a journalist. She said "I am not satisfied with the kind of work which is generally given to me. I am assigned those stories to cover which are not sufficient to actually use journalistic abilities. Moreover, male colleagues at work do not respect me" She said that she was away from her family for some months as they asked her to leave the house if she wanted to pursue her career in journalism. But after few months, they agreed on allowing her to continue her job.

The society customs define the profession of male and female. The common perception is that female should fulfill the family responsibilities and live a homely life. She should behave as an ideal wife and mother. If a female wish to pursue a job, she should select that profession which does not alter her duties at home. Female are supposed to be at house before night and that female should not work in the night shifts. With these prejudgments, female in our country started to select the career of a teacher. Women were not supposed to choose journalism as a profession otherwise they challenge the society rules and regulations. Chetna Kumari is a reporter from the local television news channel, MeerutTV24x7. She said in her interview that "I belong to a rural area. Sometimes I reach my house very late in the night due to the night shift. My neighbours always raise a question mark on my job timings. I get anxious stares of many of neighbours. I feel highly awkward." This is a common perception especially in rural areas to see journalism as a permit for indulgence. The change in the thinking of the society will ease the working of women in this profession.

A correspondent Sunita Kumari working in GaonTak TV news channel said: "When people in my area come to provide some news stories in my organization, they want male journalists to cover the story. Only when male journalists are not available then they come to the female journalists." This shows the perception of the common people towards the female journalists. They are so judgemental for women at work. 


\section{Social science, Humanities \& Education}

15 - 17 December, 2020

Berlin,Germany

Talking about the experience about working with the male colleagues, a reporter Sarika Jain said "When a female journalist works with a male video journalist in the field to cover a news story, especially during the night, people misinterpret it. This is a common perception about a female journalist when anyone saw them with male co-worker and they immediately start to presume the character of that female journalist. In return, female journalist cannot fight with everyone while covering the news story. But it feels very bad when someone judge your character."

Rehana Khatoon is a reporter in the Siwan Samachar newspaper which is published in Siwan. She shared her story with us during the interview. She said "I am working in the news media profession since last three years. I generally do the reporting of the social issues in my area. One day my neighbour came to me and asked to lend some money to her for her children college fee. She said that I must have a good salary package and that it would be easy for me lend five lakhs to her. I was shocked to hear from her that this is her perception about my salary. In reality, I even do not get the minimal salary which should be given by my organization. I have almost no savings in my bank from my salary as I get only hand to mouth salary." After the conversation, we came to know that there is a big difference between the perception about the economic life of a rural woman journalist and the reality.

\section{Conclusion}

Hard work and sincere efforts made by women journalists have enabled them to succeed in the media profession.

In the mainstream news media, few female journalists have become visible and also been given good opportunities to showcase their talent. But a good number of women are still working on lower positions where they are given very limited freedom about the way they should conduct their work. Similarly, the female journalists who are living in rural parts also face problems while doing their job but these problems may be related to social restrictions and patriarchal thinking of the people in their areas. But their professional work should be considered for praise. In this paper, we have presented the case studies of the female journalists living in urban as well as in the rural areas. 
$4^{\text {th }}$ International Conference on

\section{Social science, Humanities \& Education}

15 - 17 December, 2020

Berlin,Germany

\section{References}

1. Chowdhury, N. J. (2016). Women's Participation in Managerial Activities: A Study on Employed Women in Selected Enterprises of Bangladesh. IIUC Studies, 39-64. doi:10.3329/iiucs.v10i0.27426.

2. Brenna Coleman, "Percentage of Women in the Workforce \& Media Portrayal at Odds", Nov 9,2010 downloaded from the www.lycos .com on 22.2.2013

3. Gender and the media Rosalind Gill - Polity Press - 2013

4. Ross, K. (2001). Women at Work: Journalism as en-gendered practice. Journalism Studies, 2(4), 531-544. doi:10.1080/14616700120086404

5. RANU, T. (n.d.). GENDER AND MEDIA: STATUS OF WOMEN JOURNALIST IN HINDI PRINT MEDIA IN INDIA.

6. Inside the News: Challenges and Aspiration of Women Journalists in Asia and the Pacific, UN Women. VIOLENCE AND HARASSMENT AGAINST WOMEN IN ... newssafety.org. (n.d.). Retrieved from https://newssafety.org/uploads/IWMF.FINALA.PDF

7. PANDAY, P.K (2011), Still a Male Preserve, Women in Bangladeshi News Industry, "Reporting: Why Are Women Not Coming?” May, 2011.

8. Zameer Ahmad Bhat (2014), "Gender bias and socioeconomic problems of women in India”, Abhinav National Monthly Refereed Journal of Research in Art and Education, Vol. 3, pp 8- 13.

9. Tomar, Ranu. "Khabar Lahariya: A Feminist Critique of Mainstream Hindi Print Media." About SubVersions.

10. The fight within, The Hindu, 14 September, 2017The Better India, http://www.thebetterindia.com/37228/khabar-lahariya-women-journalists/, 2016

11. Bhandare Usha V. (2015). Women Exploitation In Media, Volume 4, Issue 2, pp:1120

12. Narayana, U. R. (2015). Mainstreaming Women in News-Myth or Reality?.Pragyaan: Journal of Mass Communication, Volume 13, Issue 1, pp: 22-26.

13. Patowary, H. (2014). Portrayal of Women in Indian Mass Media: An Investigation. Journal of Education \& Social Policy, 1(1). Vol. 1 No. 1. pp:84-92. 
$4^{\text {th }}$ International Conference on

\section{Social science, Humanities \& Education}

15 - 17 December, 2020

Berlin,Germany

14. Ira N. Gang, KunalSen, and Myeong-Su Yun (2008), Poverty in rural India: caste and tribe. Review of Income and Wealth Journal. pp: 50-70.

15. Joseph Ammu, Kalpana Sharma, (Eds.), 2006, Whose News? The Media and Women's Issues, Sage.

16. Joshi, U., Pahad, A., \& Maniar, A. (2006). Images of Women in Print Media-A

Research Inquiry., Indian Media Studies Journal 1.1,pp: 39-51.

17. https://scroll.in/article/838263/how-the-internet-is-empowering-assams-rural-women

18. Aggarwal Vir Bala, "Media and Society", Challenges and Opportunities", Concept Publishing Company, 2002

19. John Allen Hendricks, "The Twenty-First-Century Media Industry: Economic and Managerial Implications in the Age of New Media”,Marylad: Lexington Books, 2010

20. Chakraborty Prithvis, “Outstanding Women journalists” Vidura, 1996 ,33(2), pp. 11 13.

21. Bhatnagar, Vinod, "Development Dynamics of Press and journalism" Jaipur. Printwell Publication,1996

22. National Conference on Women and Media. A report, Social Welfare April 2002. 49(1), 120 Natranjan, S.A "history of the press in India" Asia Publishing House, New York 1981. pp. 140-141. Nitz, M., Reichert,

23. Prasad Kiran (2005). Women and Media: Challenging feminist discourse. The Women Press.

24. Tomar, Ranu. "Women in Media like ice on cake" .Media Vimarsh, Annual issue, OctDec. Bhopal. 2009. pg 74

25. Akhilhshvvari R Vidura, "Should Women Opt for Journalism" 27(1), 1990,pp 18-19.

26. Toni Bruce "Supportive or Hostile? Teasing or Professional? Women Sportswriters Categorize Locker Room Interaction,”,Women in Sport and Physical Activity Journal, 2002 11, no. 1 49-61,

27. Rao, L. (2001) Facets of media and gender studies in India. Feminist Media Studies 1.1. pp: $45-48$. 